\title{
Locating Women in the Naxalbari Movement: A Story of Resistance and Fabrication of the Individual Female Identity
}

\author{
Pritha Sarkar \\ Research Scholar; Indian Institute of Technology, Kanpur; spritha353@gmail.com
}

\begin{abstract}
The objective in this paper is to explore the role of women in the Naxalbari movement by studying how a woman resists all the patriarchal authorities and carves her own space in a male-dominated movement through The Naxalites: A Novel (1979), a representative text on the Naxalbari movement in Indian English Literature. The Naxalbari movement (1965-1975) is the first peasant revolution within twenty years of Indian Independence that initiated in a small village named Naxalbari situated in the Darjeeling district of West Bengal. Though there have been many scholarly studies on the movement, the representation of women and their experiences in the texts on the movement in Indian English Literature has not yet been traversed upon. The paper therefore, addresses this gap by studying the movement from the feminist standpoint through one of the representative texts. While on one hand, historical records show how women had been frontline warriors in the initial phase of the movement only to be marginalized with the spread of the movement; on the other, none of the chronicles on the movement recognize the role of women and their contributions in it. Through the text of The Naxalites: A Novel, this paper engages with such problematic and contradictory location of women through the portrayal of a female character who attempts to change the whole direction the movement with the aim to make it more sustaining. Thus, the paper tries to analyze women as a subversive force within the movement who represent the critical voice against the patriarchal framework by suggesting an alternative modus operandi while staying within the folds of the movement.
\end{abstract}

Keywords: Women, Movement, Patriarchy, Female Identity

\section{Introduction}

The objective in this paper is to explore the role of women in the Naxalbari movement (1965-1975) through a representative text in Indian English Literature named The Naxalites: A Novel (1979) by Khwaja Ahmed Abbas. The paper studies the strong participation of women in the Naxalbari movement despite the patriarchal framework operating within the movement that tried to push women to the periphery. Many assessments on the movement stress on how the participation of women in the movement enabled them to attain a certain degree of emancipation from the confinement of the patriarchal society. Yet, none of the chronicles on the movement recognize the role of women at the very core of the movement. Few narratives of surviving Naxal women have been included in the paper to acknowledge the androcentric underpinning of the movement as well as to foreground the peripheral position of women in it. Irrespective of the marginalized position, it cannot be denied that women played an indispensable role in the movement. This paper endeavors to analyze how The Naxalites: A Novel engages with this problematic and contradictory location of women through the character of Ajitha. Thus, the paper tries to analyze women as a

(c) AesthetixMS 2021. This Open Access article is published under a Creative Commons Attribution Non-Commercial 4.0 International License (http://creativecommons.org/licenses/by-nc/4.o/), which permits non-commercial re-use, distribution, and reproduction in any medium, provided the original work is properly cited. For citation use the DOI. For commercial re-use, please contact editor@rupkatha.com. 
subversive force within the movement who represent the dissenting voice of the Naxalbari movement as well as the critical voice against the patriarchal framework within the movement.

\section{The Naxalbari Movement}

The Naxalbari movement (1965-1975) is the first peasant revolution within twenty years of Indian Independence that initiated in a small village named Naxalbari situated in the Darjeeling district of West Bengal. The Tebhaga movement of 1946 that erupted in certain North and North-Eastern districts of Bengal and later spread to other parts of the country resulted in the passing of Land Ceiling Act in 1953 according to which "no farmer or landlord is entitled to hold land beyond 25 acres" (Joshi, 1979, p. 447). Further the tenants and the agricultural laborer working on the fields had to be paid half the share of the whole produce. (Joshi, 1980, pp. 453-456). However, in practice the Land Ceiling Act failed to get hold of the excessive land-holding by the rural bourgeois class consisting chiefly of zamindars and money lenders. The excess land was registered in the name of their wives or children. Moreover, they could easily escape the act by bribing local government officials and state police. Thus, there was no improvement in the situation of the farmers.

It was at this juncture that small meetings were held in different weekly village markets known as hats throughout the entire rural regions of Darjeeling district in North Bengal by the then members of Communist Party of India (Marxist) shortened as C.P.I. (M) that was trying to emerge as a significant political organisation and later held a strong base in Bengal for a long period of time. "At the initiative of Charu Majumdar, camps were organized to take political classes among tea workers and peasant activists ... sometimes it continued for two days at a stretch without any gaps ... Those who attended and took classes were fed by the peasants and tea garden workers" (Bhattacharjee, 2018, p. 9). The most important aim of these camps was to bring a change from "class in itself' to 'class for itself' among the masses. "On $18^{\text {th }}$ march 1967 , the Siliguri sub-divisional peasant convention was held at Rambola Jote" (Bhattacharjee, 2018, p. 23) by the C.P.I. (M) in the Darjeeling district of North Bengal where "a call [was given] for an armed struggle by mass organization" (Bhattacharjee, 2018, p. 23). On $7^{\text {th }}$ May decision was taken for the redistribution of land and establishment of peasant authorities in the countryside (Bhattacharjee 2018, Banerjee 2009). Accordingly, four doctrines were adopted, "1) no allowance of police in village 2) taking away arms from landlords 3) taking away the excess lands from landowners to distribute it among the peasants and 4) land for tillers" (Bhattacharjee 2018, pp. 23-24). Since the political base had already been created the doctrines passed in the joint meeting were adopted by the villagers. "The line adopted in Naxalbari was not to annihilate the landlord physically but to wage a struggle to get rid of the feudal system" (Bhattacharjee 2018, p.24) by redistributing the lands and not allowing any intervention of government authority that would favor the landlords and hence prevent the activities of the peasantry (Banerjee, 2009; Singh, 2006). The only violent activity that took place before $24^{\text {th }}$ May, 1967 was the murder of a landlord, "The farmers, sharecroppers and landless agricultural laborer of one of the villages of Naxalbari were largely against a tyrant landlord Buddhiman Tirke. When he killed a farmer named Bigal Kishan, the farmers of the area rose against him" (Das, p. 50). However, following the distribution of land and the murder of the landlord, the police forces tried to enter through Bijay Nagar Garden area on $19^{\text {th }}$ May, 1967 and again on $22^{\text {nd }}$ and $23^{\text {rd }}$ May. But they were compelled to retreat in the face of armed resistance by the peasants (Bhattacharjee, 2018, p. 24). Thereafter, the two violent incidents of Naxalbari took place on $24^{\text {th }}$ May, 1967 and $25^{\text {th }}$ May 1967 . "On $24^{\text {th }}$ May the peasants, armed with bows and arrows, resisted the police party that went to a village to arrest ... and a policeman called Sonam Wangde was killed; the next day [ $25^{\text {th }}$ of May] the police party ... fired eighteen rounds" (Sen, 1982, p. 217) against a gathering or march of women led by Dhaneswari Devi "killing the peasants that included eight 
women and three infants" (Sen, 1982, p. 217). According to a few sources, the police took up arms against the mass with an intention to frighten them, but the result was a tussle in which eight women with three infants were killed (Banerjee, 2009, p. 63). On the other hand, accounts from the mouthpiece journals of the Naxalbari movement like Liberation, records that the march was unarmed and the police fired to break the spirits of the villagers. Further in a memoir Abhijeet Das records the onset of the Movement, "the police fired at a gathering of women to spread the message of land distribution movement ... killing ten women and a child. One of the bullets went through the breast of Dhaleswari and killed the child who was wrapped in a sling on her back" (Das, 2014, p. 51). In the different narratives on the incident mentioned above the same woman is called in two names, Dhaneswari and Dhaleswari. She is named as Dhaleswari Devi in certain books like Footprints of Foot Soldiers of Abhijeet Das and Spring Thunder of Arun Mukherjee. But in most of the other books about the movement, including Sumanta Banerjee's In the Wake of Naxalbari she is named as Dhaneswari Devi. In the mouthpiece journals of Naxalbari Movement, named Liberation and Deshabrati her name is written as Dhaneswari Devi. Further in my personal interview with her son, Pavan Singha of Naxalbari and with other surviving members of the movement I found the name of the lady as Dhaneswari Devi. Hence, in this research she is addressed as Dhaneswari Devi. But in quotations, the name is kept as the author had written. Though different in approach towards the tussle, all the accounts direct towards the same fact the death of women and children resulted in an immediate violent reaction from the villagers. The incidents also prove that women were at the core of the movement at its initial stage. The first march of gathering was organized by a woman named Dhaneswari Devi. Moreover, the first martyrs of the movement too were women. Further, it was the death of women and children in the violent encounter between state machinery and the villagers that acted as a catalyst in spreading the movement to the towns, cities, university campuses of Bengal leading to the expulsion of North Bengal's Zonal members from C.P.I. (M) and formation of Communist Party of India (MarxistLeninist) shortened as C.P.I. (M.L.).

\section{Inclusion of Patriarchy in the Movement}

As long as the movement was limited to rural parts of Bengal including Naxalbari, Khoribari and Phansidewa districts of North Bengal, women fought shoulder to shoulder with men. There was no distinction of work based on gender. Men and women equally learnt using bows and arrows, rifle shooting and cooking in community kitchens. However, after the movement spread to the cities, the tasks of women were mostly limited to technical works and courier services. With the urbanization of a local protest by the intellectuals and political parties, it was the middle-class leaders of cities who dominated and directed the entire movement. It fabricated into a fight against the bourgeois class and the elite government led by the urban middle-class intelligentsia. However, the dominance of the middle-class also ensured the inclusion of their ideologies within the movement. Thus, the patriarchal characteristics of the $20^{\text {th }}$ century urban Bengal middle-class society seeped into the movement as well. As Mallarika Singha Roy has noted, "Women's participation in the movement ... has been largely deemed as supportive rather than front-ranking revolutionary activism by the Naxalite leadership" (Roy 2007, pp. 209-210). This marginalization of women in the movement by giving them the supportive roles of technical work and not associating them with the mainstream action has been further verified by some surviving Naxal women. Supriya, a female naxal activist speaks how women were reserved for the role of informers and healers, "In general female cadres were employed to do tech kaaj (technical work), mostly courier work, including the transportation of papers, arms, and information ... only a few were employed 
to organizational works like recruiting people for the party, campaigning and forming squads ... fewer women were in local committees and none were in senior positions of leadership" (Roy, 2001, pp. 191-192). The role of nursing was also reserved for women. While the movement was limited to villages and tribal population, both men and women took to the task of nursing the wounded comrades (Banerjee 2009). But the gender role division became all the more manifested as the middle-class intelligentsia dominated the movement. As Menon has mentioned, "Nursing and teaching (particularly at lower levels) are predominantly considered women's profession ... the feminization of teaching and nursing is because such work is seen as an extension of the nurturing work that women do at home" (Menon 2012, pp. 11-12). This ideology dominated the $20^{\text {th }}$ century middle-class Bengali society and the movement being dominated by this class after its urbanization was not an exception in following it. Krishna Bandopadhyay, one of the important members of the movement spoke against the care-giving and nurturing tasks accorded to women on account of the patriarchal ideology harbored by the leaders, "We women activists underwent a nursing training course in Medical College ... Now I wonder the principal idea behind this training was that our male comrades will get wounded and we women will nurse them back to battle condition! These ideas were harbored by the most progressive political party" (Bandyopadhyay, 2001, p. 87). Thus, the patriarchal ideologies of the middle-class society reflected itself in the movement. As a result of these patriarchal notions, the women in the movement were pushed to the periphery where their contributions to the movement were overshadowed by the heroic tales of the male members.

\section{Women at the Centre Stage in a Representative Text}

As the above section proves the patriarchal framework of the movement left no space for women to express their individual voices. Their contributions in the movement were not acknowledged and though in the initial phase of the movement they were equally in the forefront with the male comrades, in the later stages their roles became limited to the periphery. Since they were hardly included in any of the committees it became all the more difficult for them to voice their opinions. It is within this restricted space encircled by male figures propagating patriarchy that Khwaja Ahmad Abbas frames the character of Ajitha in The Naxalites: A Novel (1979) who not only voices her own opinion which is at the opposite end of the spectrum to that of the leaders, but is also successful in having majority favoring her opinion. There is a bit of confusion regarding the novel's publication especially since it is a movie by the director Khwaja Ahmed Abbas. Mostly it is held as a script for a Bollywood commercial movie which later was published as a book by Neogi Publications in 2015. However, research reveals that it was first written by the director to be published as a novel in the year 1979 by Lok Publications. The next year it developed into a movie. After a decade it was republished by Neogi Publications containing some pictures from the movie and an introduction by Suresh Kohli. This paper is concerned with the preliminary novel version before it was made into a movie.

Within the limited space available to women Ajitha frames her individual identity within the folds of the movement. This is the only representative text on the Naxalbari movement in Indian English Literature that presents active female participation. It explores the ability of women to provide new possible dimensions in the movement in the attempt to refine it. The novel tries to capture the essence of the urban Naxalite struggle by bringing out the dilemmas faced by young revolutionaries through various characters belonging to different sections of society. To put it in words, Ajitha is the only female character who represents the role of women involved directly in the movement participating in all of its tasks. Fighting against the gender hierarchy prevalent in the party, Ajitha is able to voice a contradictory non-violent path of struggle and thus challenge the 
established violent norms of the party. She displays the strength to stay within the movement and yet question the policies of the highest leaders. Historical surveys provide an account of how the movement acted as a medium for personal emancipation inspiring many women to join the movement in order to escape their limited boundaries. However, this text represents Ajitha who does not join the movement for any kind of personal freedom but to change the existing state authority that held complete control over the lives of the citizens crushing every dissenting voice. The novel portrays the active participation of Ajitha in the violent activities of the movement and undergoing custodial torture before being hanged. It is during this phase of imprisonment that she is able to find an alternative to continue the movement by including the masses, while moving away from the violent path of annihilation. The author portrays her as a complex character: she initially joins the movement for revenge, but in the latter half proves her maturity by suggesting an alternative mode of struggle.

Ajitha belonged to a middle-class family residing in the metropolitan city of Kolkata. Her father was an army man who died in war. The family survived on the pension received by Ajitha's mother after the demise of her father in the war. Education and professional activity harvested by the middle class resulting in cultural capital was well nourished by the family of Ajitha. Her mother wished her children to be professionals in government service. While, Ajitha's elder brother was a student in college, Ajitha was pursuing her medical studies. However, during his college years her brother joined the Naxalbari movement under the leadership of Comrade Dada to end the social inequality. Thus, similar to most of the middle-class youths, he was also driven by the "political upheaval" (Herneutix 117) that flooded the "university campuses" (Herneutix 117). He was caught by the police force while writing slogans on the city walls and taken to custody (Abbas, 1979, pp. 9395). After the death of her brother by custody torture, she was determined to join the movement to revenge against the state authority. The novel thereafter portrays the active participation of Ajitha in the violent activities of the movement and undergoing custodial torture before being hanged. Earlier, she had never thought of venturing in the movement, nor had any idea about the involvement of her brother in the movement. A first-year medical student she was engaged in her studies and interested in her relationship with Amar, her brother's friend. Amar was the son of Kolkata's DIG and was classmate of Ajitha's brother. He was interested in Ajitha and often visited their family.

But with her brother's death, her outlook changed, "The childish prattle of Ajitha was heard no more. The girl looked older and more mature" (Abbas, 1979, p. 89). At the deathbed, there were no tears but only the silent revolution of revenge, "She raised her hand, covered with the blood of her brother, and silently looked long and hard at her blood-stained hand which was a symbol of her brother's sacrifice and called for some sort of revenge" (Abbas 1979, p. 93). Ajitha's diligence towards the movement was such that she killed her lover, Amar who was involved in the movement on account of her. She obeyed the command of Comrade Dada, who represents the highest authority of the Naxalbari Movement in the city of Kolkata, and killed her lover to ensure the safety of other comrades. When Comrade Dada was informed that Amar might be a spy, he ordered that Ajitha should shoot him at point-blank to prove her loyalty to the movement as well as to save her comrades. Comrade Dada did not want to take any risk or even verify the information. But Ajitha did not contradict Comrade Dada even once. She followed the instruction and murdered her lover though she suffered from the guilt throughout the remaining months of her life. "In slow motion, she saw Anand - her Anand ... fall down ... his face a crimson-purple of flesh and blood" (Abbas 1979, p. 109). Ajitha's next display in the novel was inside the prison to be hanged the next day. Her strong political involvement is noteworthy and through her, the author depicts the active role of 
females to the movement who challenges all forms of authority be it the state authority or the highest rung of leaders in the movement.

The character of Ajitha becomes the dominating voice in questioning the violent path followed in the movement. She is the only female character who asserts her independent ideas even while remaining within the folds of the movement. Her action of murdering Amar at the order of Comrade Dada puts many questions from a feminist standpoint. By this action, she invokes criticism as she symbolized the futility of working women to love their near ones. Her murder of Amar serves as a critic for women who give up the "primary responsibility of home" (Menon, 2012, p. 13; 2001) and undertake public responsibilities independently. They can be categorized as "witch" (Gilbert and Gubar, 1979) who can go to any extent to fulfill their selfish interests. However, as the text progresses the criticism that women moving beyond the domestic sphere independently avoiding their primary responsibilities of home are selfish (Menon 2001; 2012) is also nullified through the character of Ajitha. Her introspection of the movement and her actions followed by her courage in embracing the gallows instead of being the approver ennobles her beyond the dichotomy of angel and witch. Thus, this text subverts the dichotomy into which females are categorized not only in literary writings but, as the sociological surveys reveal, in middle-class $2 \mathrm{O}^{\text {th }}$ century Bengali society as well.

With the progress of the text, the character of Ajitha becomes the dominating voice in questioning the violent path followed in the movement. She demonstrates the capacity to assert her independent ideas even while remaining within the folds of the movement. It is during her imprisonment years that her character's complexity is revealed. She challenges the state machinery by not bowing to their tortures and accepting the death sentence calmly (Abbas 120-122). Not only does she introspect her personal actions but also contemplates upon the policies of the movement and tries to find alternative modes of struggle (Abbas). Thereby, she asserts her individuality by neither escaping from the prison nor agreeing to the violence of Comrade Dada. Thus, through her letter she rejected the path of Comrade Dada though she did not try to escape from her death sentence:

"Think whether it [the killings] has led us to the goal of revolution. Not murder, but mass awakening, mass organization is the way of revolution. I am not afraid to die. You asked me to kill and I killed - even the one I loved! You asked me to die and I am dying - but on the threshold of death, I am sending this message to you to reconsider your methods" (Abbas, 1979, p. 147).

Through the posthumous letter she urges for a reconsideration of the violence propagated in the movement. Her letter actually prompts the members to focus more on mass organization and mass awakening. This echoes the chief goal of the movement: mass awareness to bring a change among the proletariats and agricultural labors "from class-in-itself to class-for-itself" (Banerjee, 2009; Bhattacharyya, 2018, p. 49). The letter reaches Comrade Dada on the eve of a major meeting through the hands of Ajitha's jail-mate who had escaped from prison. This proves that despite having the opportunity, she chose not to escape her death sentence as a mode of silent protest against the authority. By finding her own path for revolution, she acts as the source for enlightenment for the masses of individuals joining the movement. The text reveals that though her idea was opposed by Comrade Dada, the other members of the organization considered her views. Thus posthumously, she engaged in a clash with the ideologies of Comrade Dada. But the majority of the members agreed to the path proposed by Ajitha:

"One man, a peasant ... arose. 'I propose we reconsider our plan and programs in view of Comrade Ajitha's message' ... Another man arose, 'Comrades, individual terrorism won't do. 
We must organize the poor, landless labor for revolutionary action' ... Yet another man arose, 'People mistake us for common murderers. We must remove this impression' ... The tables were turned. Comrade Dada was defeated" (Abbas 1079, p. 148).

The last two lines indicate the individual stance of Ajitha against Comrade Dada who represents the highest authority in the movement. Through this incident, her independent identity becomes more dominating than the entire group of Naxalite activists led by Comrade Dada. Through her letter, she not only challenged the highest authority but also the modus operandi of the movement. By rejecting the path of annihilation, she challenges Comrade Dada's leadership and also the whole set of ideologies. Thus, posthumously she succeeds in keeping a mark of her strong individual identity by swaying the mass opinion to her favor.

Her individual identity becomes manifested twice: firstly, when she challenges the government machinery by her fearless death and secondly, when she rejects to blindly follow the orders of the supreme leader movement and chooses to analyze the policies of the movement. It is noteworthy that she finds her emancipation not through her activities in the movement but in her solitary confinement in jail that provides her the scope to reflect on her actions and decisions. However, it is not the movement that helps her to find her individual identity. Rather it was the solitary confinement in jail that provides her the opportunity to reflect on her actions to find her emancipation by voicing a new modus operandi and thus challenging the existing policies. Set against the violent patriarchal background her calm death and her short letter challenges the whole system making her the character stronger than all the males. This gets re-affirmed when she succeeds in overthrowing Comrade Dada, the male authority through the approval of her posthumous letter by most of the people in the meeting. Thus, finally we find a shift from a male authoritative figure controlling the movement on patriarchal terms to a more inclusive modus operandi suggested by a female figure.

\section{Conclusion}

The novel therefore explores how a woman finds her place in a movement led on patriarchal terms. Unlike most of the other female characters, she doesn't choose to disassociate herself from the movement but carves her own space within it. Thus, she displays the strength to stay within the movement to challenge the state authority as well as question the policies of the movement itself by proposing an alternative modus operandi. Her ability to sway the masses in her favor posthumously by her letter makes her the character stronger than all the males. Set against the violent patriarchal background, it is through the female character of Ajitha that the movement finds a new modus operandi to accomplish its goals. Thus, it is through a female figure in this text that one can locate a shift from a patriarchal and violent mode dominating the movement to a more inclusive and non-violent strategy to continue the movement. 


\section{References}

Abbas Khwaja Ahmed. (1979). The Naxalites: A Novel. Lok Publications.

Bandopadhyay Krishna. Abirata Larai. (2001). Khoj Ekhon Manabi Chetanar Potrika (Search Today - Journal of Feminist Consciousness) vol.7, pp. 4-9.

Banerjee M, Sapna. (2004). Down Memory Lane: Representations of Domestic Workers in Middle Class Personal Narratives of Colonial Bengal. Journal of Social History, vol. 37, (3), pp. 681-708.

Banerjee, Sumanta. (2009). In the Wake of Naxalbari. Sahitya Samsad.

Basu, Sajal. (1979). West Bengal: The Violent Years. Prachi Publications. (1982). Politics of Violence: A Case Study of West Bengal. Minerva Press.

Beauvoir, Simon De. (1972). The Second Sex. Translated: H.M. Parshley. Penguin Publishers.

Bhattacharjee, Amit. (2018). The Spring Thunder and Kolkata: An Epic Story of Courage and Sacrifice 196572. Setu Prakashani.

Bhasin, Kamala. (2000). Understanding Gender. Kali for Women. (1993). What is Patriarchy. Kali for Women.

Chakravarti, Sudeep. (2017). The Bengalis: Portrait of a Community. Rupa Publications.

Chowdhury, Sushital Roy. (1972). Declaration of the Revolution of the C.P.I. (M). Liberation, vol. 1, (2), pp 37.

Das, Abhijeet. (2014). Footprints of Foot-Soldiers. Setu Prakashani.

Dasgupta, Biplab. (1974). The Naxalite Movement. Allied Publishers Private Limited.

Desai, A.R. (1948). Social Background of Indian Nationalism. Popular Prakashan.

(1986). Agrarian Struggles in India after Independence. Oxford University Press.

Ghosh, Sankar. (1974). The Naxalite Movement: A Maoist Experiment. Firma K.L. Mukhopadhyay.

Gilbert Sandra, Gubar Susan. (1979). The Madwoman in the Attic. Yale University Press.

Gupta, Dipak. (2007). The Naxalites and the Maoist Movement in India: Birth, Demise, and Reincarnation. Democracy and Security, vol. 3, pp. 157-188.

Harnetiaux, Keith J. (1997). The Resurgence of Naxalism: How Great a Threat to India? Naval Postgraduate School, California. http://www.nps.edu/library.

Joshi, P.C. (1979). Agrarian Reforms Facts and Fiction. Kurukshetra. pp. 445-45o. (1975). Land Reforms in India: Trends and Perspectives. Allied Publishers Private Limited.

Lerner, Gerda. (1987). The Creation of Patriarchy. Oxford University Press.

Majumdar, Charu. (1971). Time for Revolutionary Party. Liberation, vol. 12, pp. 6-11.

Menon, Nivedita. (2001). Gender and Politics in India. Oxford University Press.

(2012). Seeing Like a Feminist. Penguin Random House.

Millet, Kate. (1970). Sexual Politics. Doubleday and Co.

Ray, Rabindra. (1993). The Naxalites and their Ideology. Oxford University Press.

Roy Singha, Mallarika. (2007). Magic Moments of Struggle: Women's Memory of the Naxalbari Movement in West Bengal, India (1967-75) Indian Journal of Gender Studies, Sage Publications, vol. 16, pp. 205-232.

(2010). Gender and Radical Politics in India: Magic Moments of Naxalbari (1967-1975). Routledge. 
9 Locating Women in the Naxalbari Movement: A Story of Resistance and Fabrication of the Individual Female Identity

Roy, Srila. (2001). The Everyday Life of Revolution: Gender, Violence and Memory. South Asian Research Journal, vol. 27, (2), pp.187-204.

Roy, Debal, Singha. (2004). Peasant Movements in Post-Colonial India: Dynamics of Mobilization and Identity. Sage Publications.

Sen, Sunil. (1982). Peasant Movement in India, Mid-Nineteenth and Twentieth Century. K.P. Bagchi and Sons.

Showalter, Elaine. (2004). Towards a Feminist Poetics. In K.M. Newton (Ed.), Twentieth Century Literary Theory (pp. 216-220). Macmillan.

(1999). A Literature of Their Own: British Women Novelists from Bronte to Lessing. Princeton University Press.

Author: Pritha Sarkar is a research scholar of English discipline in the department of Humanities and Social Science, Indian Institute of Technology, Kanpur. Her areas of interest include Movement Literatures, Feminism, Women Studies and Indian English Writing on Bengal. 